\title{
EFFECT OF DIETARY CARROT MEAL SUPPLEMENTATION ON PRODUCTIVITY AND CARCASS CHARACTERISTICS OF ARBOR ACRE BROILER CHICKENS AGED 22 TO 42 DAYS
}

\author{
NG’AMBI, J. W. - MoKGOPe, P. K. - Brown, D. - MANYelo, T. G. ${ }^{*}$ \\ Department of Agricultural Economics and Animal Production, University of Limpopo, P/Bag \\ X1106, Sovenga 0727, South Africa \\ *Corresponding author \\ e-mail: manyelo.t.g@gmail.com \\ (Received $6^{\text {th }}$ May 2019; accepted $16^{\text {th }}$ Jul 2019)
}

\begin{abstract}
This study determined the effect of carrot meal supplementation on productivity and carcass characteristics of Arbor acre broiler chickens aged 22 to 42 days in Limpopo province, South Africa. A total of 200 female Arbor acre broiler chickens were randomly allocated to five treatments with five replicates, each having 8 birds, in a completely randomized design. The supplementation levels were 0 (FA0), 20 (FA20), 50 (FA50), 75 (FA75) or 100 (FA100) g of carrot meal per kg DM feed. The results showed that dietary carrot meal supplementation had no $(\mathrm{P}>0.05)$ effect on growth rate, live weight and carcass characteristics of female Arbor acre broiler chickens aged 22 to 42 days. Carrot meal supplementation improved feed intake, feed conversion ratio, metabolisable energy intake and nitrogen retention of Arbor acre broiler chickens aged 22 to 42 days. Dietary feed intake, feed conversion ratio, live weight, metabolisable energy intake and nitrogen retention were optimized at different dietary carrot meal supplementation levels of 52.8, 63.8, 38.0, 42.0 and $44.3 \mathrm{~g} / \mathrm{kg}$ DM feed, respectively. It is concluded that carrot meal supplementation improved intake, feed conversion ratio, metabolisable energy and nitrogen retention of female Arbor acre broiler chickens aged 22 to 42 days.
\end{abstract}

Keywords: metabolisable energy, meat sensory attributes, vitamin $C$, diets, performance

\section{Introduction}

Poultry production is nutritionally, economically and socially important in Limpopo province and the world as a whole. Chicken production is an important source of income and employment, and it contributes substantially to food security among rural people in Africa (Ng'ambi et al., 2012). Much of the poultry meat comes from broiler chickens. Not only are broiler chickens heavier at an early age but they also have better feed conversion ratio (Havenstein, 2004). High mortality in broiler chickens leads to poor productivity and low income for rural people. Carcasses from broiler chickens have high fat content and, thus, reduced carcass quality and feed efficiency. High fat content meat is also not liked by consumers (Steenfeldt et al., 2007). Excessive fat is one of the main problems faced by the broiler chicken industry, since it does not just reduce carcass quality and feed efficiency but also causes consumer rejection and difficulties in meat processing (Macajova et al., 2003).

There is some evidence that carrot meal supplementation reduces chick mortality and improves carcass characteristics (Steenfeldt et al., 2007). Carrot (Daucus carota) is a commonly consumed vegetable species belonging to the family Apiacea, which grows in temperate regions of Europe, Asia and Africa (Hammam, 2014). It contains a lot of active ingredients such as steroids, tannins, flavonoids, and carotene (Jasicka-Misiak et al., 2005; Vasudevan et al., 2006). Aromatic plants such as carrots can increase feed intake, feed conversion ratio, weight gain and can improve the oxidative stability of tissues (Ürüşan and Bölükbaşı, 2017). Carrot meal has been tested for its potential as food in livestock industry 
(Rust and Buskirk, 2008; Steenfeldt et al., 2007); however, its prospect in Arbor acre broiler-based diets has not yet been fully exploited. Information generated in this study will help in formulating strategies aimed at improving productivity and carcass characteristics of Arbor acre broiler chickens. Improvement of productivity of broiler chickens may enhance the economic, nutritional and social status of broiler chicken farmers. Therefore, the aim of this study was to determine the effects of supplementing diets with carrot meal on feed intake, digestibility, live weight, growth, feed conversion ratio, mortality and carcass characteristics of Arbor acre broiler chickens.

\section{Materials and methods}

\section{Study site and experimental design}

This study was conducted as part of the Pahlomoje Poultry Project, Shikwane village in Maruleng Municipality, South Africa. The project site is $64 \mathrm{~km}$ north-west of Tzaneen. The chickens were raised on commercial starter mash up to 21 days old before the experiment commenced. Prior to the start of the experiment the chickens were fed a $22 \%$ crude protein $(\mathrm{CP})$ diet that would satisfy their nutritional requirements according to NRC (1994). A total of 200 female Arbor acre broiler chickens (Females were used because there were not enough males), weighing $650 \pm 4 \mathrm{~g}$ per chicken were randomly assigned to five treatments with five replicates, each replicate having 8 Arbor acre female chickens in a completely randomized design. Thus, chickens were raised on 25 floor pens in an environmentally controlled house and temperature maintained at 30 to $33{ }^{\circ} \mathrm{C}$ and 23 to $25{ }^{\circ} \mathrm{C}$ during the starter and grower phase, respectively. Lighting was provided continuously (Fig. 1). The chicks were vaccinated against Newcastle virus disease and infectious bronchitis. A grower diet was offered from day 22-42 days with different carrot supplementation levels (Table 1). The nutrient composition of the treatments is presented in Table 2. The diets contained similar nutrients but different carrot meal levels ranging from zero to $100 \mathrm{~g}$ per $\mathrm{kg}$ DM. The carrot meal contained $12 \%$ crude protein, $17.1 \mathrm{MJ}$ of gross energy $/ \mathrm{kg} \mathrm{DM}, 18 \%$ ash, $13.3 \%$ neutral detergent fibre (NDF), $8.8 \%$ acid detergent fibre (ADF) and 300-700 $\mathrm{mg} / \mathrm{kg}$ dry matter (DM) of vitamin C. The grower diet was formulated and produced by a commercial feed company, Meadow Feeds, South Africa. Feed and water were offered ad libitum throughout the experiment.

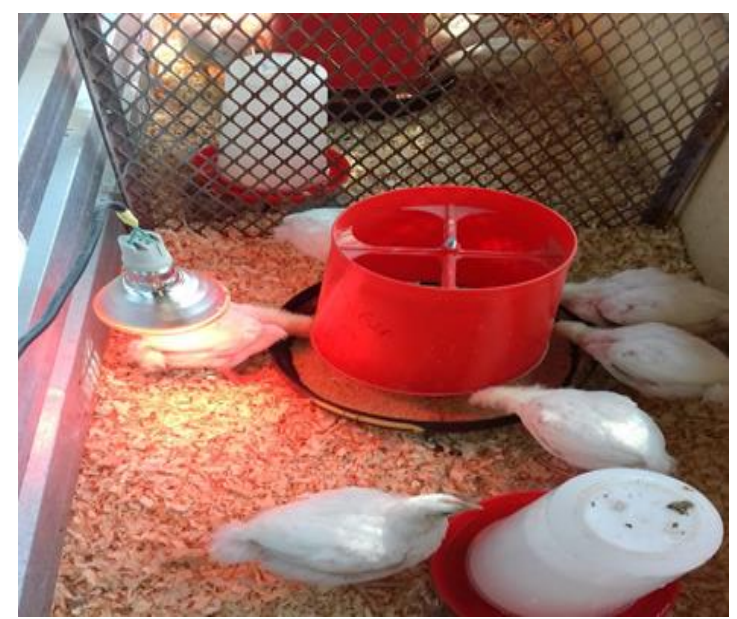

Figure 1. Ross 308 broiler chickens feeding on treatment diet 
Ng'ambi et al.: Effect of dietary carrot meal supplementation on productivity and carcass characteristics of Arbor acre broiler chickens aged 22 to 42 days

$$
-12339 \text { - }
$$

Table 1. Diet composition of grower feed for Arbor acre chickens

\begin{tabular}{c|c}
\hline Ingredient & Quantity (\%) \\
\hline Yellow maize & 567 \\
Sunflower meat & 100 \\
Full fat soya meal & 290 \\
Fish meal & 10 \\
Monocalcium phosphate & 13.6 \\
Limestone & 13.6 \\
Iodised salt & 0.5 \\
DL Methionine & 0.3 \\
L Threonine & 0.0 \\
Vitamin/mineral premix & 5.0 \\
Total & 1000 \\
CP (\%) & 20 \\
Energy (MJ/kg DM) & 16.9 \\
\hline
\end{tabular}

Table 2. Nutrient composition of the diets for Arbor acre broiler chickens (units are in $\mathrm{g} / \mathrm{kg}$ DM except energy as MJ/kg DM feed and dry matter as $\mathrm{g} / \mathrm{kg}$ feed)

\begin{tabular}{c|c|c|c|c}
\hline \multirow{2}{*}{ Diet code } & \multicolumn{4}{|c}{ Nutrient } \\
\cline { 2 - 5 } & Dry matter & Energy & Protein & $\begin{array}{c}\text { Carrot meal } \\
\text { supplement }\end{array}$ \\
\hline $\mathrm{UA}_{0}$ & 930 & 16.9 & 200 & 0 \\
$\mathrm{UA}_{20}$ & 930 & 16.9 & 200 & 20 \\
$\mathrm{UA}_{50}$ & 930 & 16.9 & 200 & 50 \\
$\mathrm{UA}_{75}$ & 930 & 16.9 & 200 & 75 \\
$\mathrm{UA}_{100}$ & 930 & 16.9 & 200 & 100 \\
\hline
\end{tabular}

\section{Data collection}

The initial live weights of the chickens were taken at the beginning of the experiment and weekly weights were taken thereafter using the electronic weighing scale (RADWAG AS 220/C/2). Weekly feed intakes were determined. Daily mean growth rates and feed conversion ratios were calculated. Digestibility was done when the chickens were between 35 and 42 days. Digestibility was conducted in specially designed metabolic cages with separate watering and feeding troughs. Four birds were randomly selected from each replicate and transferred to metabolic cages to measure apparent digestibility. A three-day acclimatization period was allowed prior to a threeday collection period. Droppings voided by each bird were collected daily at $09 \mathrm{~h} 00$. Care was taken to avoid contamination from feathers, scales, debris and feeds. Dry matter and nitrogen contents of the diets, refusals and faeces were determined. At $42 \mathrm{~d}$ of age, 3 chickens per pen were slaughtered according to the rules and regulations of University of Limpopo Animal Research Ethics Committee. After slaughtering, carcass weight of each chicken was measured. Dressing percentage was determined by dividing carcass weight by live weight and then multiplying by 100 . Breast, fat pad, thigh, wing, drumstick, gizzard and liver weights were measured using an electronic scale. Breast 
meat samples were further analysed for meat sensory attributes. Breast meat was prepared and the skin was left on the meat samples. Nothing was added to the meat samples to add taste. An oven set at $105^{\circ} \mathrm{C}$ was allowed to preheat prior to cooking. The meat samples were put in trays and they were covered with aluminium foil to prevent water loss. Thereafter, the trays with meat were put in an oven for approximately $60 \mathrm{~min}$ and the meat samples were turned after every $10 \mathrm{~min}$. Samples were cut into small $5 \mathrm{~cm}$ cubic pieces and served immediately after cooking to a total of 30 panel composed of students and staff members of the University of Limpopo that were from the Sepedi, Setswana, Tshivenda and Tsitsonga tribes. The panel was shown how to infer and record scores for each parameter. The waiting period between meats samples tastings was $10 \mathrm{~min}$. Distilled water with lemon was given to panel to clean their palate between sub-sample measurements to avoid crossover effects. Breast meat was evaluated for tenderness, juiciness and flavour using a 5-point ranking scale (AMSA, 1995) (Table 3).

Table 3. Evaluation scores used by the sensory panel

\begin{tabular}{c|c|c|c}
\hline \multirow{2}{*}{ Score } & \multicolumn{3}{|c}{ Sensory attributes } \\
\cline { 2 - 4 } & Tenderness & Juiciness & Flavour \\
\hline 1 & Too tough & Much too dry & Very bad flavor \\
2 & Tough & Dry & Poor flavor \\
3 & Neither tough nor tender & Neither dry nor juicy & Neither bad nor good flavor \\
4 & Tender & Juicy & Good flavor \\
5 & Too tender & Too juicy & Very good flavor \\
\hline
\end{tabular}

\section{Chemical analysis}

Dry matter and nitrogen contents of the diets, refusals, faeces and meat samples were determined as described by AOAC (2008). Neutral and acid detergent fibre contents were analysed by AOAC (2008) methods. The energy of the diets, excreta samples and meat were determined using an adiabatic bomb calorimeter IKA ${ }^{\circledR}$ C5003 Control.

\section{Statistical analysis}

Data on feed intake, feed conversion ratio, growth rate, live weight and carcass characteristics of Arbor acre broiler chickens were analyzed using the general linear model procedures of the statistical analysis of variance (SAS, 2008). Where there was a significant difference, the Duncan test for multiple comparisons was used to test the significance of differences between treatment means (SAS, 2008). The dose - responses in feed intake, live weight, growth rate, feed conversion ratio, metabolisable energy, nitrogen retention and carcass characteristics of the chickens were models using the following quadratic equation:

$$
\mathrm{Y}=\mathrm{a}+\mathrm{b}_{1} \mathrm{x}+\mathrm{b}_{2} \mathrm{x}^{2}
$$

where $\mathrm{y}=$ feed intake, digestibility, live weight, growth rate, feed conversion ratio, metabolisable energy, nitrogen retention and carcass characteristics; $a=$ intercept; $b_{1}$ and $b_{2}=$ coefficients of the quadratic equation; $x=$ dietary carrot meal supplementation level and $-b_{1} / 2 b_{2}=x$ value for optimum response. The quadratic model was fitted to 
experimental data by means of the NLIN procedure of SAS (SAS, 2008). The quadratic model was used because it gave the best fit.

The relationships between carrot meal supplementation and optimal responses in meat tenderness, flavour and juiciness were models using a linear regression equation (SAS, 2008) of the form:

$$
\mathrm{Y}=\mathrm{a}+\mathrm{bx}
$$

where $\mathrm{Y}=$ optimal tenderness, juiciness and flavour; $\mathrm{a}=$ intercept; $\mathrm{b}=$ coefficient of the linear equation and $\mathrm{x}=$ dietary carrot meal supplementation level.

\section{Results}

Results of the effect of carrot meal supplementation on feed intake, growth rate, feed conversion ratio, live weight, metabolisable energy intake and nitrogen retention of female Arbor acre broiler chickens aged 22 to 42 days are presented in Table 4. Carrot meal supplementation had no effect $(\mathrm{P}>0.05)$ on growth rate of female Arbor acre broiler chickens aged 22 to 42 days. Broiler chickens on a diet supplemented with $50 \mathrm{~g}$ of carrot meal per $\mathrm{kg} \mathrm{DM}$ had higher $(\mathrm{P}<0.05)$ feed intakes than those on a diet not supplemented with carrot meal, and those on diets supplemented with 20 or $100 \mathrm{~g}$ of carrot meal per kg DM feed. Feed intakes of female Arbor acre broiler chickens aged 22 to 42 days were optimized at dietary carrot meal levels of $52.8\left(\mathrm{r}^{2}=0.888\right)($ Table 5).

Carrot meal supplementation improved dietary intake of female Arbor acre broiler chickens aged 22 to 42 days. However, these improvements did not have any impact on growth rates of the chickens. Similarly, improvements in dietary intake, feed conversion ratio, metabolisable energy intake and nitrogen retention did not result in any improvement of live weights of the chickens. Female broiler chickens on a diet supplemented with $50 \mathrm{~g}$ of carrot meal per $\mathrm{kg}$ DM had higher $(\mathrm{P}<0.05)$ live weights than those on diets supplemented with 20 or $100 \mathrm{~g}$ of carrot meal per $\mathrm{kg}$ DM feed. Broiler chickens on a diet supplemented with $20 \mathrm{~g}$ of carrot meal per $\mathrm{kg}$ DM feed had higher $(\mathrm{P}<0.05)$ live weights than those on a diet supplemented with $100 \mathrm{~g}$ of carrot meal per kg DM. Live weights of female Arbor acre broiler chickens aged 22 to 42 days were optimized at dietary carrot meal levels of $63.8\left(\mathrm{r}^{2}=0.780\right)$ (Table 5). Supplementation with $50 \mathrm{~g}$ of carrot meal per kg DM feed improved $(\mathrm{P}<0.05)$ feed conversion ratio. Feed conversion ratios of female Arbor acre broiler chickens aged 22 to 42 days were optimized at dietary carrot meal levels of $38.0\left(\mathrm{r}^{2}=0.673\right)$ (Table 5).

In the present study, dietary intake and feed conversion ratio and live weight of female Arbor acre broiler chickens aged 22 to 42 days were optimized at different dietary carrot meal supplementation levels of 52.8 and $63.8 \mathrm{~g} / \mathrm{kg} \mathrm{DM}$ feed, respectively. Female broiler chickens on a diet supplemented with $20 \mathrm{~g}$ of carrot meal per $\mathrm{kg}$ DM had higher $(\mathrm{P}<0.05)$ metabolisable energy intakes than those on a diet not supplemented with carrot meal and those on diets supplemented with 50, 75 or $100 \mathrm{~g}$ of carrot meal per $\mathrm{kg}$ DM. Broiler chickens on diets supplemented with 50 or $75 \mathrm{~g}$ of carrot meal per $\mathrm{kg}$ DM had higher $(\mathrm{P}<0.05)$ metabolisable energy intakes than those on a diet not supplemented with carrot meal. Metabolisable energy intakes of female Arbor acre broiler chickens aged 22 to 42 days were optimized at dietary carrot meal levels of 42.0 $\left(\mathrm{r}^{2}=0.385\right) \mathrm{g} / \mathrm{kg}$ DM (Table 5). Female broiler chickens on diets supplemented with 20 or $50 \mathrm{~g}$ of carrot meal per kg DM had higher $(\mathrm{P}<0.05)$ nitrogen retention values than 
those on a diet not supplemented with carrot meal and those on diets supplemented with 75 or $100 \mathrm{~g}$ of carrot meal per kg DM. Nitrogen retention of female Arbor acre broiler chickens aged 22 to 42 days were optimized at dietary carrot meal levels of 44.3 $\left(\mathrm{r}^{2}=0.603\right) \mathrm{g} / \mathrm{kg} \mathrm{DM}$ (Table 5). Carrot meal supplementation improved dietary metabolisable energy intakes of female Arbor acre broiler chickens aged 22 to 42 days. In the present study, metabolisable energy intake and nitrogen retention of female Arbor acre broiler chickens were optimized at different carrot meal supplementation levels of 42.0 and $44.3 \mathrm{~g} / \mathrm{kg}$ DM feed, respectively. This means carrot meal levels for optimal metabolisable intake and nitrogen retention intake will depend on the variable of interest.

Table 4. Effect of carrot meal supplementation on feed intake ( $\mathrm{g} D M /$ bird/day), growth rate ( $g /$ bird/day), feed conversion ratio (FCR) ( $g$ DM feed/g live weight gain), live weight (g/bird aged 42 days), metabolisable energy (MJ/kg DM) and nitrogen retention (g/bird/day) of female Arbor acre broiler chickens aged 22 to 42 days

\begin{tabular}{|c|c|c|c|c|c|c|}
\hline \multirow{2}{*}{ Variables } & \multicolumn{5}{|c|}{ Treatment } & \multirow{2}{*}{ SE } \\
\hline & FA, & FA20 & FAs0 $_{50}$ & FAt5 $_{75}$ & FA $_{100}$ & \\
\hline DM intake & $140.0^{\mathrm{b}}$ & $150.5^{b}$ & $172.0^{\mathrm{a}}$ & $160.3^{\mathrm{ab}}$ & $147.5^{\mathrm{b}}$ & 3.80 \\
\hline Growth rate & 33.3 & 29.5 & 27.8 & 31.8 & 28.0 & 1.13 \\
\hline FCR & $5.3^{\mathrm{a}}$ & $4.5^{\mathrm{ab}}$ & $3.3^{\mathrm{b}}$ & $4.2^{\mathrm{ab}}$ & $4.0^{\mathrm{ab}}$ & 0.22 \\
\hline Live weight & $1834^{\mathrm{ab}}$ & $1755^{\mathrm{b}}$ & $1891^{\mathrm{a}}$ & $1835^{\mathrm{ab}}$ & $1609^{c}$ & 36.84 \\
\hline ME intake & $9.4^{\mathrm{c}}$ & $13.8^{\mathrm{a}}$ & $11.4^{\mathrm{b}}$ & $11.4^{\mathrm{b}}$ & $10.4^{\mathrm{bc}}$ & 0.388 \\
\hline $\mathrm{N}$ retention & $2.0^{\mathrm{b}}$ & $2.8^{\mathrm{a}}$ & $3.0^{\mathrm{a}}$ & $2.0^{\mathrm{b}}$ & $2.0^{\mathrm{b}}$ & 0.115 \\
\hline
\end{tabular}

a,b,c Means in the same row not sharing a common superscript are significantly different $(\mathrm{P}<0.05)$ SE: Standard error

Table 5. Carrot meal supplementation levels for optimal feed intake (g/bird/day), feed conversion ratio ( $g$ DM feed/g live weight gain), live weight (g/bird aged 42 days), metabolisable energy (ME) (MJ/kg DM) and nitrogen retention ( $\mathrm{g} /$ bird/day) of female Arbor acre broiler chickens aged 22 to 42 days

\begin{tabular}{c|c|c|c|c}
\hline Trait & Formula & $\mathbf{r}^{2}$ & $\begin{array}{c}\text { Carrot } \\
\text { meal }\end{array}$ & $\begin{array}{c}\text { Optimal Y- } \\
\text { value }\end{array}$ \\
\hline Feed intake & $\mathrm{Y}=137.884+1.0559 \mathrm{x}+-0.0094 \mathrm{x}^{2}$ & 0.888 & 52.8 & 166.8 \\
FCR & $\mathrm{Y}=5.2775+-0.0510 \mathrm{x}+0.0004 \mathrm{x}^{2}$ & 0.780 & 63.8 & 3.65 \\
Live weight & $\mathrm{Y}=1781.939+4.7089 \mathrm{x}+-0.0615 \mathrm{x}^{2}$ & 0.673 & 38.0 & 1872 \\
Apparent ME & $\mathrm{Y}=10.427+0.0841 \mathrm{x}+-0.0008 \mathrm{x}^{2}$ & 0.385 & 42.0 & 12.4 \\
N retention & $\mathrm{Y}=2.15894+0.2811 \mathrm{x}+-0.0003 \mathrm{x}^{2}$ & 0.603 & 44.3 & 2.78 \\
\hline
\end{tabular}

$r^{2}$ : regression coefficient. Carrot meal: carrot meal supplementation level for optimal variable

Results of the effect of carrot meal supplementation on carcass characteristics of female Arbor acre broiler chickens aged 42 days are presented in Table 6. Carrot meal supplementation had no effect $(\mathrm{P}>0.05)$ on carcass, breast, drumstick, thigh, liver, gizzard and fat pad weights of female Arbor acre broiler chickens aged 42 days. Results of the effect of carrot meal supplementation on tenderness, juiciness and flavour of meat of female Arbor acre broiler chickens aged 42 days are presented in Table 7. Carrot 
meal supplementation did not improve $(\mathrm{P}>0.05)$ meat tenderness and flavour of female Arbor acre broiler chickens aged 42 days. Female broiler chickens supplemented with 20,50 or $100 \mathrm{~g}$ of carrot meal per kg DM feed produced meat with higher $(\mathrm{P}<0.05)$ juiciness than those of meat from a diet not supplemented with carrot meal and those on a diet supplemented with $75 \mathrm{~g}$ of carrot meal per $\mathrm{kg}$ DM. A positive relationship was observed between carrot meal supplementation to the diets of female Arbor acre broiler chickens and meat juiciness $\left(r^{2}=0.085\right)$. Carrot meal supplementation did not affect tenderness and flavour of female Arbor acre broiler chicken meat. However, carrot meal supplementation improved the juiciness of female Arbor acre broiler chicken meat. Thus, there was a weak but positive relationship between carrot meal supplementation and juiciness of female Arbor acre broiler chicken meat.

Table 6. Effect of carrot meal supplementation on carcass characteristics $(g)$ of female Arbor acre broiler chickens aged 42 days

\begin{tabular}{c|c|c|c|c|c|c}
\hline \multirow{2}{*}{ Variable } & \multicolumn{5}{|c|}{ Treatment } & \multirow{2}{*}{ SE } \\
\cline { 2 - 6 } & FA0 & FA $_{20}$ & FA50 & FA 75 & FA100 $_{n}$ & \\
\hline Carcass & 1569 & 1434 & 1534 & 1461 & 1526 & 26.03 \\
Breast & 205 & 221 & 207 & 214 & 202 & 8.42 \\
D/stick & 102 & 99 & 88 & 89 & 96 & 2.15 \\
Thigh & 108 & 112 & 104 & 76 & 107 & 5.75 \\
Liver & 68 & 62 & 62 & 55 & 54 & 3.01 \\
Gizzard & 41 & 34 & 32 & 37 & 33 & 1.65 \\
Fat pad & 39 & 43 & 44 & 31 & 42 & 2.62 \\
\hline
\end{tabular}

SE: standard error

Table 7. Effect of carrot meal supplementation level on tenderness, juiciness and flavour of meat of female Arbor acre broiler chickens aged 42 days

\begin{tabular}{|c|c|c|c|c|c|c|}
\hline \multirow{2}{*}{ Sensory attributes } & \multicolumn{5}{|c|}{ Treatment } & \multirow{2}{*}{ SE } \\
\hline & FA0 & $F_{2} A_{20}$ & FA50 & FA 75 & FA 100 & \\
\hline Juiciness & $2.50^{\mathrm{b}}$ & $3.50^{\mathrm{a}}$ & $3.70^{\mathrm{a}}$ & $2.50^{\mathrm{b}}$ & $3.60^{\mathrm{a}}$ & 0.153 \\
\hline Tenderness & 3.30 & 3.30 & 3.00 & 3.00 & 3.30 & 0.131 \\
\hline Flavour & 3.00 & 3.10 & 3.00 & 3.00 & 3.20 & 0.131 \\
\hline
\end{tabular}

${ }^{a, b}$ Means in the same row not sharing a common superscript are significantly different $(\mathrm{P}<0.05)$

SE: standard error

\section{Discussion}

In the present study, carrot meal supplementation had no effect on growth rate of female Arbor acre broiler chickens aged 22 to 42 days. Carrot meal supplementation improved dietary intake of female Arbor acre broiler chickens aged 22 to 42 days. However, these improvements did not have any impact on growth rates of the chickens. Similarly, improvements in dietary intake, feed conversion ratio, metabolisable energy intake and nitrogen retention did not result in any improvement of live weights of the chickens. These results are similar to those of Erhan and Bölükbaşı (2017) who found out that supporting the diet with citrus peel oil did not change the weight of the broilers. According to $\mathrm{Yu}$ et al. (2005), the obtained results in this study may be attributed to 
antioxidant and antimicrobial properties of carrot meal. However, the present results are contrary to those of Ürüşanet al. (2018) who observed improvements in live weights of chickens supplemented with carrot meal. Similarly, Abdu et al. (2012) reported improvements in live weights of rabbits with carrot meal supplementation. This might also be because large amounts of easily-fermented components as sugars and soluble non-starch polysaccharides contribute some energy to the chickens Steenfeldts et al. (2007).

Supplementation with $50 \mathrm{~g}$ of carrot meal per $\mathrm{kg}$ DM feed improved feed conversion ratio. Rizal et al. (2010) reported an improvement in feed conversion ratio of broiler chickens supplemented with carrot meal. Improvements in dietary feed conversion ratio observed in the present study are similar to those observed by Hammershøj et al. (2005) and Hammershøj et al. (2010) reported improvements in feed conversion ratio of laying hens when they were supplemented with carrot meals. However, Khan (2019) reported no improvements in feed conversion ratio of broiler chickens fed carrot pulp. In the present study, dietary intake and feed conversion ratio and live weight of female Arbor acre broiler chickens aged 22 to 42 days were optimized at different dietary carrot meal supplementation levels of 52.8 and $63.8 \mathrm{~g} / \mathrm{kg}$ DM feed, respectively. This means that carrot meal levels for optimal productivity will depend on the particular variable of interest. This has implications on ration formulation where carrot meal is included.

Carrot meal supplementation improved dietary metabolisable energy intakes of female Arbor acre broiler chickens aged 22 to 42 days. These results are similar to those of Magouze et al. (1998) who observed that carrot meal supplementation in growing rabbits improved their metabolisable energy intakes. However, El-Kerdawy et al. (1992) found that carrot meal supplementation to the diets of growing rabbits decreased their metabolisable energy intakes. Similarly, Steenfeldts et al. (2007) observed a decrease in metabolisable energy intakes of laying hens supplemented with carrot meal. The results of the present study indicate that carrot meal supplementation increased nitrogen retention in female Arbor acre broiler chickens aged 22 to 42 days. Their findings may imply that an alteration of tissues takes place, particularly muscle and fat deposits, which may differ in nutrient digestion (Moran and Bilgili, 1990). However, these results contradict with those of El-Kerdawy et al. (1992), which indicated that carrot meal supplementation to the diets of growing rabbits decreased nitrogen retention. Similarly, Steenfeldts et al. (2007) found that nitrogen retention in laying hens supplemented with carrot meal was increasing. In the present study, metabolisable energy intake and nitrogen retention of female Arbor acre broiler chickens were optimized at different carrot meal supplementation levels of 42.0 and $44.3 \mathrm{~g} / \mathrm{kg}$ DM feed, respectively. This means carrot meal levels for optimal metabolisable intake and nitrogen retention intake will depend on the variable of interest.

Carrot meal supplementation had no effect on carcass, breast, drumstick, thigh, liver, gizzard and fat pad weights of female Arbor acre broiler chickens aged 42 days. Ürüşanet al. (2018) reported increase in hot carcass weight and carcass yield of broiler chickens feed carrot seed oil authors indicated that increase carcass weights which were observed in many studies, occurred because of the appetizer properties of plant extracts by increasing the gastric digestion liquor. Carrot meal supplementation did not affect tenderness and flavour of female Arbor acre broiler chicken meat. Meat sensory attribute values of tenderness and flavour were similar across the dietary treatments. It is not clear how carrot meal supplementation affect the sensory attributes of broiler chickens and this may require further studies. However, carrot meal supplementation 
improved the juiciness of female Arbor acre broiler chicken meat. Thus, there was positive relationship between carrot meal supplementation and juiciness of female Arbor acre broiler chicken meat. No such information was found for either indigenous or broiler chicken breeds. Further research is needed to deepen the knowledge in this area.

\section{Conclusion}

Carrot meal supplementation did not have any effect on growth rate, live weight, carcass weight, meat tenderness and flavour of Arbor acre broiler chickens aged 22 to 42 days. However, carrot meal supplementation improved intake, feed conversion ratio, metabolisable energy intake, nitrogen retention and meat juiciness of female Arbor acre broiler chickens aged 22 to 42 days. As a result, carrot meal can be added in the diet of broilers as a beneficial dietary supplement which contains natural antioxidants. Optimal improvements of feed intake, FCR, live weight, metabolisable energy intake and nitrogen retention were achieved at different carrot meal supplementation levels. Thus, carrot meal levels for optimal productivity will depend on the parameter in question. This has a lot of implications in diet formulations where carrot meal is included. Further studies are recommended to repeat and confirm results of this study.

Acknowledgements. The authors wish to acknowledge Agri-SETA and Meadow feeds for financial support.

\section{REFERENCES}

[1] Abdu, S. B., Jokthan, G. E., Hassan, M. R., Adamu, H. Y., Yashim, S. M., Ikani, E. (2012): Effects of inclusion levels of carrot leaf meal on performance of growing rabbits. - World Journal of Life Science and Medical Research 2(2): 65-70.

[2] AMSA (1995): Research Guidelines for Cookery, Sensory Evaluation and Instrumental Measurements of Fresh Meat. - American Meat Science Association, Chicago, IL.

[3] AOAC (2008): Association of Analytical Chemists, Official Methods of Analysis. 17 $7^{\text {th }}$ Ed. AOAC, Washington, DC.

[4] El-kerdawy, D. M. A., Rashwan, A. A., Ibrahim, H., El-gendy, K. M. (1992): Digestibility, growth rate, carcass traits and some physiological aspects of growing New Zealand white rabbits as affected by partial substitution of concentrates with carrot-tops hay and feeding time. - Egyptian Journal of Rabbit Science 2(1): 61-71.

[5] Erhan, M. K., Bölükbaşı, Ş. C. (2017): Citrus peel oils supplementation in broiler diet: effects on performance, jejunum microflora and jejunum dietary inclusion of turmeric (Curcuma longa) and cinnamon (Cinnamomum verum) powders on performance, organs relative weight and some 1mmune system parameters in broiler chickens. - Poultry Science 2: 153-163.

[6] Hammam, F. H. (2014): Protective effect of carrot juice against the toxicity of carbon tetrachloride on liver and kidneys in rabbits. - World Journal of Pharmacy and Pharmaceutical Sciences 3: 1229-1239.

[7] Hammershøj, M., Steenfeldt, S. (2005): Effect of blue lupin (Lupinus angustifolius) in organic layer diets and supplementation with foraging material on layer performance and some egg quality parameters. - Poultry Science 84: 723-733. 
[8] Hammershøj, M., Kidmose, U., Steenfeldt, S. (2010): Deposition of carotenoids in egg yolk by short-term supplement of coloured carrot (Daucus carota) varieties as forage material for egg-laying hens. - Journal of Science and Food Agriculture 90(7): 1163-71.

[9] Havenstein, G. B., Mahmoud, F. W., Eisen, E. J. (2004): The effect of dietary phosphorus on heat shock protein mRNAs during acute heat stress in male broiler chickens (Gallus gallus). - British Journal 137: 11-18.

[10] Jasicka-Misiak, I., Wieczorek, P. P., Kafarski, P. (2005): Crotonic acid as a bioactive factor in carrot seeds (Daucus carota L.). - Phytochemistry 66: 1485-1491.

[11] Macajova, M. D., Lamosova, D., Zenman, E. (2003): Physiological effects of leptin insulin and triamcin nolon on adult Japanese quail. - Acta Veterinary Brunes 72: 515522.

[12] Khan, S. (2019): Utilization carrot pulp as corn replacement in the broiler diet. - Journal of Agriculture and Veterinary Science 12(2): 72-74.

[13] Magouze, F. I., Mahmound, S. A., El-kelawy, H. M., Homouda, I. A., Alla, S. A. Z. G. (1998): Productive and reproductive performance of rabbits fed diets containing different agricultural by-products: productive performance of growing rabbits. - Egyptian Journal of Rabbit Science 8(1): 49-60.

[14] Moran, E., Bilgili, S. (1990): Processing losses, carcass quality, and meat yields of broiler chickens receiving diets marginally deficient to adequate in lysine prior to marketing. Poultry Science 69: 702-710.

[15] Ng'ambi, J. W., Sebola, N. A., Norris, D. (2012): Effect of Hoodia gordonii leaf meal supplementation at finisher stage on productivity, carcass characteristics and meat sensory attributes of male Ross 308 broiler chickens. - African Journal of Biotechnology 11(95): 16205-16209.

[16] NRC (1994): Nutrient Requirements of Poultry. $9^{\text {th }}$ Revised Ed. - National Academy Press, Washington, DC.

[17] Rizal, Y., Mahata, M. E., Andriani, M., Wu, G. (2010): Utilization of juice wastes as corn replacement in the broiler diet. - World Academy of Science, Engineering and Technology 44: 1459-1462.

[18] Rust, S., Buskirk, D. (2008): Feeding carrots or sugar beets to cattle. - Cattle Call 13(4).

[19] SAS (2008): Proprietary Software Release 9.2. - Statistical Analysis Systems Institute, Inc., Cary, NC.

[20] Steenfeldt, S., Kjaer, J. B., Engberg, R. M. (2007): Effect of feeding silages or carrots as supplements to laying hens on production performance, nutrient digestibility, gut structure, gut microflora and feather pecking behaviour. - British Poultry Science 48: 454-468.

[21] Ürüşan, H., Bölükbaşı, Ş. C. (2017): Effects of dietary supplementation levels of turmeric powder (curcuma longa) on performance, carcass characteristics and gut microflora in broiler chickens. - Journal of Animal and Plant Sciences 27(3): 732-736.

[22] Ürüşan, H., Erhan, M. K., Bölükbaş1, S. C. (2018): Effect of cold-press carrot seed oil on the performance, carcass characteristics, and shelf life of broiler chickens. - Journal of Animal and Plant Sciences 28(6): 1662-1668.

[23] Vasudevan, M., Gunnam, K. K. (2006): Parle Antinociceptive and anti-inflammatory properties of Daucus carota seeds extract. - Journal of Health Sciences 52: 598-606.

[24] Yu, L. L., Zhou, K. K., Parry, J. (2005): Antioxidant properties of coldpressed black caraway, carrot, cranberry, and hemp seeds oils. - Food Chemistry 91: 723-729. 